\title{
Soils associated with rock outcrops in the Brazilian mountain ranges Mantiqueira and Espinhaço
}

\author{
VINICIUS M. BENITES ${ }^{1,3}$, CARLOS ERNESTO G. R. SCHAEFER ${ }^{2}$, FELIPE N. B. SIMAS ${ }^{2}$ \\ and HUMBERTO G. SANTOS ${ }^{1}$
}

(received: September 16, 2004; accepted: July 10, 2007)

\begin{abstract}
Soils associated with rock outcrops in the Brazilian mountain ranges Mantiqueira and Espinhaço). Espinhaço and Mantiqueira are two mountain ranges of great importance in Brazil. In the uppermost parts of these areas, unique ecosystems occur, generally associated with rock outcrops, they are collectively called High Altitude Rocky Complexes. These environments show distinct soil and biota characteristics in relation to the surrounding biome. The soils are generally shallow, coarse textured, with high $\mathrm{Al}^{3+}$ and varying amounts of organic matter. Entisols, Inceptsols and Histosols are dominant, directly associated with the rock outcrops, and forming a complex mosaic of soils. Some of these soils are endemic, based on peculiar conditions of parent materials, topography and vegetation, and this pedodiversity is important for detecting unique and endangered soils. In these soils, organic matter is highly humified, with a great amount of soluble forms and conspicuous presence of charcoal. Spodic horizons and dark water rivers are typically associated with quartzite and quartzite outcrops, formed by illuviation of organic compounds, being less common in granitic rocks. The very low nutrient content of these soils and other environmental limitations required the development of specific physiological and morphological plant adaptations. Most high altitude environments are unstable under current climatic conditions, and anthropic interventions may be accelerating this process. Detailed soil surveys are necessary for a better understanding of the role of these soils in ecological processes and for the development of adequate conservation policies.
\end{abstract}

Key words - high altitude rocky complexes, lithosols, organic soils

RESUMO - (Solos associados aos afloramentos rochosos das Serras do Espinhaço e da Mantiqueira). A Serra do Espinhaço e a Serra da Mantiqueira são duas cadeias de grande importância para o Brasil. Nas partes mais altas destas serras encontram-se ecossistemas com características singulares, associados aos afloramentos rochosos, denominados Complexos Rupestres de Altitude. Esses ambientes apresentam características do solo e da vegetação distintas das áreas adjacentes. Os solos são em geral rasos, arenosos, com alta saturação de alumínio e teores variados de matéria orgânica. Neossolos Litólicos, Cambissolos e Organossolos são as classes de solo dominantes, diretamente associadas aos afloramentos, formando um mosaico de solos. Alguns solos encontrados nestes ambientes são endêmicos, em função das características peculiares da rocha matriz, da topografia e da vegetação, e sua preservação é estratégica por se tratar de solos raros e ameaçados de extinção. A matéria orgânica desses solos apresenta alto grau de humificação, com grande quantidade de frações solúveis, e a presença generalizada de fragmentos de carvão. Horizontes espódicos e rios negros estão tipicamente associados às áreas de afloramento de arenito e quartzito, sendo formados pela iluviação de compostos orgânicos, e sendo menos comuns nas áreas de granito. O oligotrofismo destes solos, associado a outras limitações de ordem química e física, induzem o desenvolvimento de estratégias de adaptação fisiológica e morfológica por parte da vegetação. A maioria destes ecossistemas é instável sob a condição climática atual, e a intervenção antrópica é um fator de aceleração do processo de degradação. A descrição detalhada dos solos nestes ambientes é fundamental para um melhor entendimento do seu papel nos processos ecológicos e para o desenvolvimento de políticas de conservação.

Palavras-chave - complexos rupestres de altitude, neossolos litólicos, organossolos

\section{Introduction}

The Brazilian geomorphology is characterized by flat or dissected plateaux and low tablelands and plains, having few mountainous areas with altitudes higher than

1. Embrapa Solos, Rua Jardim Botânico 1024, Jardim Botânico, 22460-000 Rio de Janeiro, RJ, Brazil

2. Universidade Federal de Viçosa, Depto. de Solos, Av P.H. Rolfs s/n, Campus Universitário, 36571-000 Viçosa, MG, Brazil

3._Corresponding author: vinicius@cnps.embrapa.br
2,000 m. However, in the southeast region, marking the borders of the Atlantic Forest biome, two great mountain ranges formed by different lithologies occur as part of the Atlantic mobile belt zone: (i) "Serra do Espinhaço", composed mainly by quartzite; and (ii) "Serra da Mantiqueira", with predominance of plutonic rocks (granite) and high grade metamorphics (migmatites, gneiss) and a few sparse quartzite areas (e.g. "Serra do Ibitipoca").

These mountain ranges are extremely important in a geo-environmental sense. There occur several 
watersheds that feed important urban centers of southeastern Brazil, as well as important Atlantic Forest fragments, which are hotspots of biodiversity (Myers et al. 2000). Hence, several conservation units have been created in order to protect these fragile environments.

In the uppermost parts of these mountain ranges, a distinct ecosystem named High Altitude Rocky Complexes (Semir 1991, Benites et al. 2003a) occurs, with peculiar soil and vegetation characteristics. Although apparently homogeneous, there can be observed a considerable diversity of pedoenvironments and associated vegetation mosaics, greatly determined by local topography and microenvironmental aspects. Markedly, rock outcrops are widespread, regardless of the predominant lithology.

Perhaps associated to the fact that these environments are unsuitable for agriculture, because of either chemical or topographic limitations, these areas are often permanently protected by conservation units. A great number of endangered and endemic species are found in these highland refuges (Joly 1970), highlighting their importance for biodiversity preservation and scientific studies (Biodiversitas 1999). Normally, at small-scale pedological surveys, soils associated with rock outcrops are mapped in units that do not display the existing variety of soil types. Few studies on soil identification and characterization were done in such environments, despite their great ecological importance (Volkoff et al. 1984, Benites et al. 2001, 2005, Dias et al. 2002, Simas et al. 2005).

The objective of this study is to give an overview about chemical and physical characteristics of the soils associated with rock outcrops in the Espinhaço and Mantiqueira ranges, illustrating the great pedological diversity observed and the ecological importance of these ecosystems. We hope that it provides the basis and the necessary incentive for future studies on plant ecology and ecophysiology.

\section{Material and methods}

Study sites - Soil samples over High Altitude Rocky Complexes were collected in 9 conservation units, such as national and state parks, environmental protection areas and private wildlife preservations (table 1). The conservation units were located along both latitudinal and altitudinal gradients, in areas of "Caatinga", "Cerrado" and Atlantic Rain Forest biomes, in which High Altitude Rocky Complexes are locally present at the highest positions. All studied conservation units are in Espinhaço Range and Mantiqueira Range, where the predominant lithology is quartzite and plutonic rocks, respectively (Benites et al. 2001, 2005, Simas et al. 2005).

Table 1. Descriptive characteristics of conservation units with High Altitude Rocky Complexes where the soils were sampled.

\begin{tabular}{|c|c|c|c|c|c|c|}
\hline Conservation unit & $\begin{array}{l}\text { Number } \\
\text { of cases }\end{array}$ & Coordinates & $\begin{array}{c}\text { Mean } \\
\text { altitude } \\
\text { (meters) }\end{array}$ & $\begin{array}{l}\text { Regional } \\
\text { biome }\end{array}$ & $\begin{array}{l}\text { Köppen } \\
\text { climate }\end{array}$ & Lithology \\
\hline $\begin{array}{l}\text { "Parque Nacional da } \\
\text { Chapada Diamantina" }\end{array}$ & 6 & $\begin{array}{l}12^{\circ} 31^{\prime}, \mathrm{S} \\
41^{\circ} 33^{\prime} \mathrm{W}\end{array}$ & 900 to 1100 & "Caatinga" & $\mathrm{Aw}$ & Quartzite \\
\hline $\begin{array}{l}\text { "Parque Estadual de } \\
\text { Diamantina" }\end{array}$ & 3 & $\begin{array}{l}18^{\circ} 14^{\prime}, \mathrm{S} \\
43^{\circ} 36^{\prime}, \mathrm{W}\end{array}$ & 1000 to 1300 & "Cerrado" & Cwa & Quartzite \\
\hline $\begin{array}{l}\text { "Parque Nacional da } \\
\text { Serra do Cipó" }\end{array}$ & 6 & $\begin{array}{l}19^{\circ} 30^{\prime}, \mathrm{S} \\
43^{\circ} 44^{\prime} \mathrm{W}\end{array}$ & 900 to 1200 & "Cerrado" & Cwa & Quartzite \\
\hline $\begin{array}{l}\text { "Parque Estadual de } \\
\text { Itacolomi" }\end{array}$ & 7 & $\begin{array}{l}20^{\circ} 17^{\prime}, \mathrm{S} \\
43^{\circ} 30^{\prime} \mathrm{W}\end{array}$ & 1000 to 1400 & "Cerrado" & Cwa & Quartzite \\
\hline $\begin{array}{l}\text { "Parque Estadual de } \\
\text { Ibitipoca" }\end{array}$ & 9 & $\begin{array}{l}21^{\circ} 33^{\prime}, \mathrm{S} \\
43^{\circ} 54^{\prime} \mathrm{W}\end{array}$ & 1400 to 1700 & $\begin{array}{l}\text { Atlantic Rain } \\
\text { Forest }\end{array}$ & $\mathrm{Cwb}$ & Quartzite \\
\hline $\begin{array}{l}\text { "Parque Nacional de } \\
\text { Caparaó" }\end{array}$ & 6 & $\begin{array}{l}20^{\circ} 25^{\prime}, \mathrm{S} \\
41^{\circ} 57^{\prime}, \mathrm{W}\end{array}$ & 2300 to 2700 & $\begin{array}{l}\text { Atlantic Rain } \\
\text { Forest }\end{array}$ & $\mathrm{Cwb}$ & Granite \\
\hline $\begin{array}{l}\text { "Parque Estadual da } \\
\text { Serra do Brigadeiro" }\end{array}$ & 9 & $\begin{array}{l}20^{\circ} 40^{\prime}, \mathrm{S} \\
42^{\circ} 31^{\prime} \mathrm{W}\end{array}$ & 1400 to 1700 & $\begin{array}{l}\text { Atlantic Rain } \\
\text { Forest }\end{array}$ & $\mathrm{Cwb}$ & Migmatite \\
\hline $\begin{array}{l}\text { "Reserva Particular de } \\
\text { Mitra do Bispo" }\end{array}$ & 9 & $\begin{array}{l}22^{\circ} 10^{\prime}, \mathrm{S} \\
44^{\circ} 23^{\prime} \mathrm{W}\end{array}$ & 1700 to 2000 & $\begin{array}{l}\text { Atlantic Rain } \\
\text { Forest }\end{array}$ & $\mathrm{Cwb}$ & Granite \\
\hline $\begin{array}{l}\text { "Parque Nacional de } \\
\text { Itatiaia" }\end{array}$ & 8 & $\begin{array}{l}22^{\circ} 29^{\prime}, \mathrm{S} \\
44^{\circ} 33^{\prime} \mathrm{W}\end{array}$ & 1800 to 2300 & $\begin{array}{l}\text { Atlantic Rain } \\
\text { Forest }\end{array}$ & Cwb & Sienite \\
\hline
\end{tabular}


Soil sampling and characterization - Sixty-three samples of surface horizons and 22 complete profiles of soils associated with rock outcrops were collected. Soils were air dried and sieved to $2 \mathrm{~mm}$. The particle size (coarse sand, fine sand, silt, and clay) was determined in the $<2 \mathrm{~mm}$ fraction according to Embrapa (1997). Free-iron was extracted with dithionite-citrate-bicarbonate $\left(\mathrm{Fe}_{\mathrm{DCB}}\right), \mathrm{pH}$ in water and exchangeable $\mathrm{Ca}+\mathrm{Mg}$ and $\mathrm{Al}^{3+}$ were also determined according to Embrapa (1997). Total soil organic carbon was determined by the wet combustion method (Yeomans \& Bremner 1988). The fractionation of humic substances was used to determine the humic acid fraction (HA), fulvic acid fraction (FA) and the alkaline extract/ humin (AE/H) ratio (Benites et al. 2003c). The complete profiles were classified according to Brazilian Soil Classification System (Embrapa 1999).

\section{Results and discussion}

Soil chemical and physical characteristics - The soils associated with rocky outcrops in Mantiqueira and Espinhaço ranges have low nutrient content (dystrophic), yellowish/brownish hues, coarse texture, high exchangeable aluminum levels and dark colored surface horizons due to organic matter accumulation (table 2). The low level of soil fertility is related to nutrient losses by leaching, enhanced by high drainage, and low nutrient content of the parent material, especially in quartzite areas or in deep saprolite.

Soils on quartzite have lower carbon and nutrient content (table 2), indicating an ongoing degradation process promoted by intense leaching and lesser retention by lacking clays. The soils developed on igneous rocks show a slightly higher silt and clay content than soils developed on quartzite (table 2). Part of these fractions is composed by poor crystalline Fe oxides, as indicated by the $\mathrm{Fe}_{\mathrm{DCB}}$ and $\mathrm{Fe}_{\mathrm{ox}}$ levels (Benites et al. 2001).

The soil has an acid reaction, favoring dissolution of kaolinite and aluminossilicates, and $\mathrm{Al}^{3+}$ saturates the exchange complex. Exchangeable $\mathrm{Al}^{3+}$ levels are higher in soils associated with granitic/gneiss outcrops, especially in the Mantiqueira, since igneous rocks contain high amounts of aluminum and iron, compared with the quartzite (table 2).

The extremely low fertility status of these soils conditioned the development of survival strategies by the vegetation, involving physiological and morphological adaptations. Some nutrients, particularly $\mathrm{P}$, which is extremely limiting for plant development, show negligible amounts in some soils. In igneous rock outcrops, despite the generalized lack of $\mathrm{P}$ in the soil, the soils still maintain some reserve of this element in primary apatite minerals. Plants and their mycorrhizal associations release organic acids capable of solubilizing P directly from the rock (Van Breeman et al. 2000). In quartzitic outcrops, where rock apatite is absent, $\mathrm{P}$ uptake mechanisms are even more remarkable. An example of the adaptative strategies to the low fertility is the presence of insectivorous plants like Drosera sp. that are frequently observed in these environments. The organic P assimilated from insects may represent a considerable part of available $\mathrm{P}$ for these

Table 2. Mean chemical and physical characteristics of surface horizons of soils associated with rock outcrops in different conservation units of Mantiqueira and Espinhaço Ranges $(n=63)$ and the mean values of soil characteristics over quartzite and granite lithologies. $(\mathrm{cs}=$ coarse sand, $\mathrm{fs}=$ fine sand, $\mathrm{TOC}=$ total organic carbon, $\mathrm{FA}=$ fulvic acid fraction, $\mathrm{HA}=$ humic acid fraction, $\mathrm{AE} / \mathrm{H}=$ alcaline extract/humin ratio).

\begin{tabular}{|c|c|c|c|c|c|c|c|c|c|c|c|}
\hline \multirow{2}{*}{ Conservation unit/Lithology } & cs & fs & silt & clay & \multirow{2}{*}{$\mathrm{pH}$} & $\mathrm{Ca}+\mathrm{Mg}$ & $\mathrm{Al}^{+3}$ & \multirow{2}{*}{$\frac{\mathrm{TOC}}{\left(\mathrm{g} \mathrm{kg}^{-1}\right)}$} & FA & HA & \multirow{2}{*}{$\begin{array}{c}\mathrm{AE} \\
\mathrm{H}\end{array}$} \\
\hline & \multicolumn{4}{|c|}{$(\%)$} & & \multicolumn{2}{|c|}{$\left(\mathrm{cmol}_{\mathrm{c}} \mathrm{kg}^{-1}\right)$} & & \multicolumn{2}{|c|}{ (\% TOC) } & \\
\hline "Parque Nacional da Chapada Diamantina" & 71 & 17 & 7 & 6 & 3.8 & 1.10 & 2.07 & 105 & 9 & 26 & 0.8 \\
\hline "Parque Estadual de Diamantina" & 23 & 64 & 7 & 6 & 4.1 & 0.12 & 2.73 & 60 & 13 & 27 & 1.1 \\
\hline "Parque Nacional da Serra do Cipó" & 17 & 47 & 13 & 13 & 4.6 & 0.14 & 2.96 & 33 & 19 & 29 & 1.2 \\
\hline "Parque Estadual de Itacolomi”" & 61 & 29 & 5 & 6 & 4.4 & 0.30 & 3.84 & 50 & 11 & 34 & 1.4 \\
\hline "Parque Estadual de Ibitipoca" & 74 & 11 & 5 & 10 & 4.0 & 0.22 & 9.99 & 77 & 15 & 43 & 2.2 \\
\hline Quartzite Rock & 49 & 33 & 7 & 8 & 4.2 & 0.37 & 4.32 & 65 & 13 & 32 & 1.7 \\
\hline "Parque Nacional de Caparaó" & 36 & 33 & 17 & 13 & 5.0 & 0.47 & 6.84 & 122 & 24 & 47 & 2.1 \\
\hline "Parque Estadual de Serra do Brigadeiro" & 47 & 24 & 17 & 13 & 4.4 & 0.33 & 4.41 & 58 & 19 & 28 & 1.2 \\
\hline "Reserva Particular de Mitra do Bispo" & 50 & 24 & 11 & 15 & 4.7 & 0.27 & 11.21 & 83 & 23 & 41 & 2.3 \\
\hline "Parque Nacional de Itatiaia" & 46 & 20 & 17 & 18 & 4.7 & 0.35 & 13.22 & 95 & 22 & 32 & 2.2 \\
\hline Granite Rock & 45 & 25 & 15 & 15 & 4.7 & 0.35 & 8.92 & 90 & 21 & 37 & 1.9 \\
\hline
\end{tabular}


plants considering the extreme low availability of this element in the soil and in the parent rock (Benites et al. 2003b).

In these highland environments, irrespective of the predominant lithology, biogeochemical cycling of nutrients is essential for vegetation maintenance. The highest nutrient levels are always verified in superficial, organic matter rich horizons (Benites et al. 2001). The concentration of thin roots in the soil surface, forming a continuous root-carpet, is a commonly verified mechanism to reduce nutrient losses (Simas et al. 2005). Under shrubby or more closed vegetation, accumulation of fibric material positioned directly on the rock can occur. These horizons show high nutrient content as a result of the biogeochemical cycling by the vegetation, differently from other organic materials in soils associated with rock outcrops (Benites et al. 2003a).

Soils associated with rock outcrops show high level of fibric organic material, showing low bulk density, due to the accumulation of light organic matter derived from non decomposed vegetal residues (table 2). However, most of the organic substances in soils associated with rocky outcrops are strongly humified, with predominance of the humic acid fraction (table 2). Fulvic acid content is higher than those found in other subtropical/tropical soils (Benites et al. 2000), indicating high mobility of organic substances in these pedoenvironments. The relationship between alkaline soluble humic fraction and the humin fraction $(\mathrm{AE} / \mathrm{H}$ ration) indicates the predominance of low molecular weight organic substances (table 2). The humic acids are responsible for most of the cation exchange capacity (CEC) and water retention capacity of these soils, especially in the organic materials, where clay minerals are virtually absent (Benites et al. 2003a).

Soil genesis and classification - In general, soils associated with rock outcrops are weakly developed, showing properties strongly influenced by the parent materials. Solum depth is extremely variable, as a function of local topography, with very shallow soils on steep slopes and deeper soils on more stable areas. Rock outcrops occur scattered amongst soil patches (figure 1), or very small soil spots are formed directly on bare rock (figure 2). The presence of a deep pre-weathered saprolite makes a great influence over soil fertility, as soils developed from these mantles are generally poor, even though they can be shallow. There are clear, contrasting differences between shallow soils on either granitic or quartzitic rocks. In granitic rocks, boulders associated with deep weathered mantles are observed and most arboreal species are found between large rock outcrops. In the quartzitic rocks, fracturing, schistosity and faulting are prominent features controlling soil/vegetation development (figure 3).

Due to their shallow depths, most of soils associated with rock outcrops are classified as "Neossolos Litólicos" in the Brazilian Soil Classification System (Embrapa 1999), which correspond to the Entisol order of the US Soil Taxonomy (USDA 1998) and to the Leptosols of the FAO soil classification system (FAO 1998). These soils are normally characterized by a surface A horizon located directly on the underlying rock or on a $\mathrm{C}$ horizon or saprolite (partially weathered parent rock). The A horizon assumes a great importance as a classification criterion at low category levels, subdividing the Entisol into different groups (Embrapa 1999).

The Humic Entisol is the most common soil order associated with rock outcrops in the Mantiqueira Ranges.

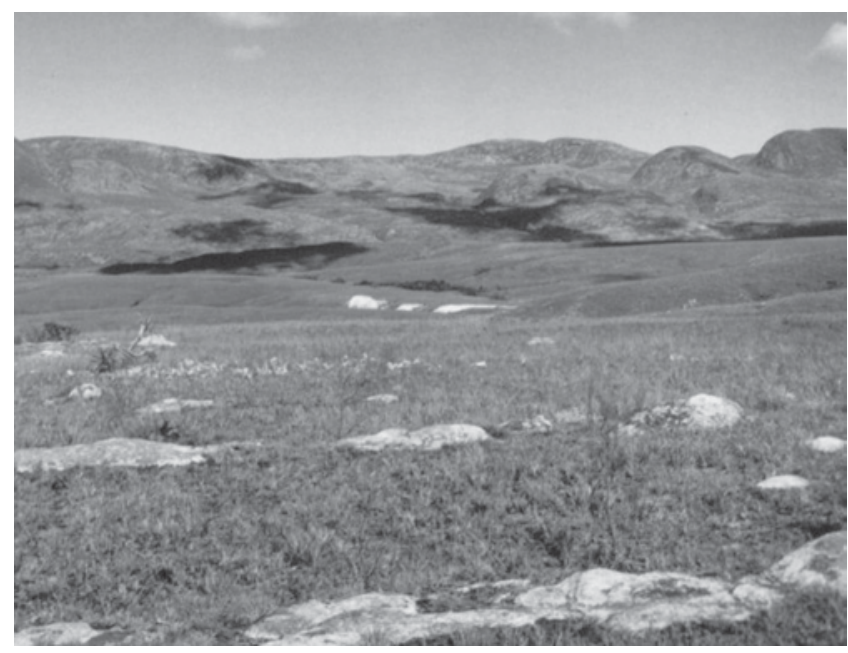

Figure 1. Rock outcrop between associated soils patches in "Serra do Cipó".

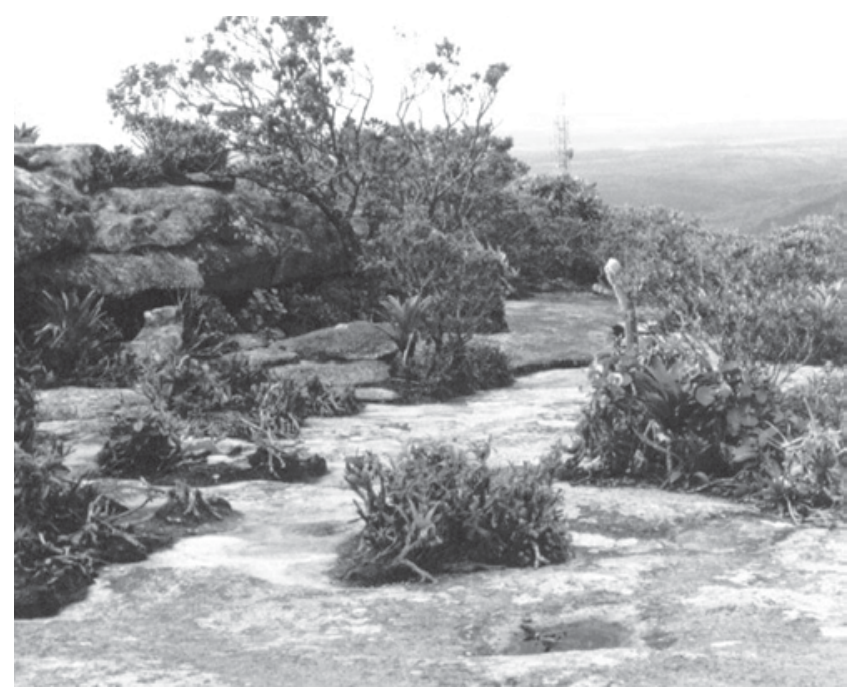

Figure 2. Islands of soil on rock outcrop landscape of the Diamantina plateau. 


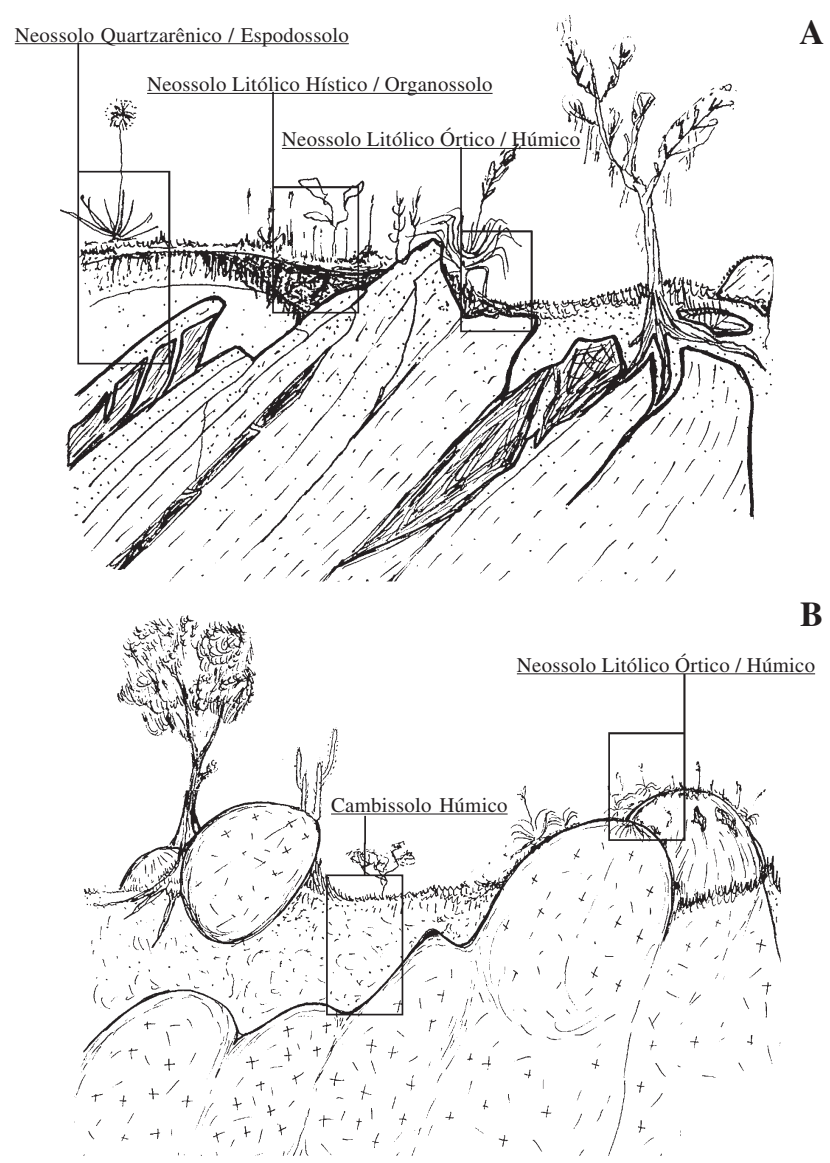

Figure 3. Schematic view of soils associated with quartzite outcrops (A) and with granite outcrops (B).

It is characterized by a humic A horizon located directly on the parent rock (Embrapa 1999), which is usually granite, sienite or migmatite. Sometimes the surface horizon presents organic carbon content and Munsell color typical of humic horizons, but is shallower than $20 \mathrm{~cm}$, characterizing a moderate A horizon. In this case, the soil is classified as Dystrophic Entisol (table 3). However, soil depth separates virtually identical pedoenvironments. Thus, a close association between Humic and Dystrophic Entisols is very common.

In the Espinhaço mountain range, where smoothed structural landforms are frequently observed on the top mountain, shallow coarse textured soils are covered by a detritic pavement (stony lag deposit), composed of quartz gravels and, occasionally, Fe concretions (petroplinthite) predominate. Normally these soils are nutrient deficient, have low organic carbon content, and are classified as Dystrophic Entisol or Psamitic Entisol (high sand content). They are characterized by a moderate A horizon overlying a coarse textured mineral layer of up to $50 \mathrm{~cm}$, which rests on rock (quartzite) or deep saprolite (schists/pellitic rocks) (table 3). When the solum is deeper than $50 \mathrm{~cm}$, composed basically of quartz sand and gravels, it is classified as "Neossolo Quartzarênico" (Embrapa 1999) corresponding to Quartzipsamments (USDA 1998) and Arenosols (FAO 1998). These soils are found in "Serra do Ibitipoca" (Dias et al. 2002, Benites et al. 2003a,b) and in some areas of "Serra do Cipó" and the Diamantina Plateau (Benites et al. 2003a, Schaefer et al. 2002) where quartzite is the main lithology (figure 4).

Soils with an incipient $B$ horizon underlying a humic A horizon, classified as "Cambissolos Húmicos" (Embrapa 1999), which correspond to the Inceptisols (USDA 1998) and to the Cambisols (FAO 1998), are also found associated with rock outcrops and saprolites (Volkoff et al. 1984, Benites et al. 2001, 2003b, Dias et al. 2002, Simas et al. 2005). Although infrequent, these soils are found on both quartzite and igneous/metamorphic lithologies. They usually occupy lower areas, which are stable enough enabling colluvial accumulation, in situ pedogenesis and $\mathrm{B}$ horizon differentiation. However, on quartzite, due to the normally sandy texture of the soils, the occurrence of the Quartzipsamment soils is more common than the Humic Inceptisols.

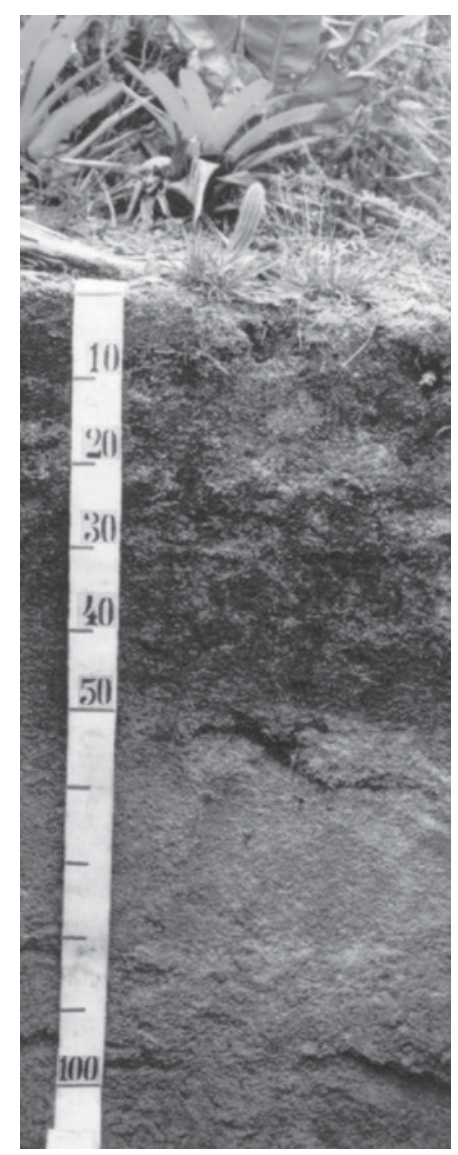

Figure 4. Quartzipsamment profile in the "Parque Estadual de Ibitipoca". 
Organic matter accumulates in soils associated with rock outcrops due to unfavorable conditions for microbial decomposition. The main factors are: lack of nutrients, high $\mathrm{Al}^{3+}$ levels and lower temperatures, all of which reduce microbial activity and decomposition rates, leading to organic $\mathrm{C}$ accumulation. This, in turn, enables the establishment of vegetation by feedback mechanisms, because the accumulated organic layer ultimately enhances nutrients and water retention, supporting plant development. Also, mesothermic climates in these highlands, with cool winters can also account for a relative decrease of carbon mineralization, leading to high soil organic matter content.

Organic compounds also form complexes with $\mathrm{Al}^{3+}$, reducing the aluminum phytotoxicity. The nature of the organic matter in the soil associated with rock outcrops is another important factor, which promotes organic substances preservation in the soil and long turn over. As a result of the incomplete burning of plant residues by natural fires, charcoal fragments were added to soil. Humic substances of high aromaticity, showing condensed structures of high stability, were formed in these soils as a consequence of the charcoal transformation (Benites et al. 2005).

As a consequence of organic matter accumulation, soil horizons with total organic carbon content higher than $120 \mathrm{~g} \mathrm{~kg}^{-1}$ are formed, characterizing organic horizons (Embrapa 1999). When the organic horizon is not $>40 \mathrm{~cm}$, the soils are classified as Histic Entisol (table 3 ). These soils are commonly observed in rock outcrops, forming well-defined patches of organic surface horizons (fibric or sapric) resting directly on the rock. Frequently, the development of these soils is favored by the local topography.

Marshy peats occur when low temperature and high humidity simultaneously occur, as in the highest portions of the Mantiqueira range (above of 2,000 m a.s.1.), or when structurally controlled hydromorphic areas are

Table 3. Characteristics of Entisols (Lithic Udorthents) associated with different rock outcrops in Mantiqueira and Espinhaço. ( $\mathrm{cs}=$ coarse sand, $\mathrm{fs}=$ fine sand, $\mathrm{Fe}_{\mathrm{DCB}}=$ Free Fe extracted with dithionite-citrate-bicarbonate, TOC = total organic carbon, $\mathrm{FA}=$ fulvic acid fraction, $\mathrm{HA}=$ humic acid fraction, $\mathrm{AE} / \mathrm{H}=$ alcaline exctract/humin ratio).

\begin{tabular}{|c|c|c|c|c|c|c|c|c|c|c|c|c|c|c|}
\hline \multirow{2}{*}{ Horizon } & \multirow{2}{*}{$\frac{\text { Depth. }}{(\mathrm{cm})}$} & \multirow{2}{*}{$\begin{array}{c}\text { Munsell } \\
\text { color }\end{array}$} & $\mathrm{cs}$ & fs & silt & clay & \multirow{2}{*}{$\frac{\mathrm{Fe}_{\mathrm{DCB}}}{\left(\mathrm{g} \mathrm{kg}^{-1}\right)}$} & \multirow{2}{*}{$\mathrm{pH}$} & \multirow{2}{*}{\multicolumn{2}{|c|}{$\frac{\mathrm{Ca}+\mathrm{Mg} \mathrm{Al} \mathrm{Al}^{+3}}{\left(\mathrm{cmol}_{\mathrm{c}} \mathrm{kg}^{-1}\right)}$}} & \multirow{2}{*}{$\frac{\text { TOC }}{\left(\mathrm{g} \mathrm{kg}^{-1}\right)}$} & \multirow{2}{*}{\multicolumn{2}{|c|}{$\begin{array}{ll}\text { FA } \quad \text { HA } \\
(\% \text { TOC })\end{array}$}} & \multirow{2}{*}{$\frac{\mathrm{AE}}{\mathrm{H}}$} \\
\hline & & & \multicolumn{4}{|c|}{$(\%)$} & & & & & & & & \\
\hline \multicolumn{15}{|c|}{ "Neossolo Litólico húmico"1 (quartzite) - "Chapada Diamantina" } \\
\hline $\mathrm{A}_{\mathrm{h}}$ & $0-20$ & $2.5 / 0$ & 7 & 58 & 25 & 10 & 0.7 & 4.6 & 0.2 & 2.0 & 60 & 10 & 47 & 1.3 \\
\hline \multicolumn{15}{|c|}{ "Neossolo litólico distrófico"1 (migmatite) - "Serra do Brigadeiro" } \\
\hline A & $0-15$ & $2 / 12.5 \mathrm{Y}$ & 51 & 23 & 14 & 12 & 1.8 & 4.5 & 0.3 & 5.1 & 71 & 12 & 30 & 0.7 \\
\hline \multicolumn{15}{|c|}{ "Neossolo litólico psamítico"1 (quartzite) - "Serra do Cipó" } \\
\hline A & $0-8$ & $3 / 17.5 \mathrm{YR}$ & 80 & 11 & 5 & 4 & 0.3 & 4.3 & 0.2 & 0.1 & 14 & 23 & 33 & 1.3 \\
\hline $\mathrm{C}$ & $8-45$ & $5 / 27.5 \mathrm{YR}$ & 65 & 24 & 7 & 4 & 0 & 5.0 & 0.0 & 0.0 & 3 & - & - & - \\
\hline \multicolumn{15}{|c|}{ "Neossolo litólico distrófico"1 (quartzite) - Ibitipoca } \\
\hline A & $0-16$ & 2/1 10YR & 12 & 44 & 18 & 26 & 40.7 & 4.7 & 0.1 & 5.0 & 57 & 21 & 39 & 1.5 \\
\hline \multicolumn{15}{|c|}{ "Neossolo litólico distrófico"1 (quartzite) - Ibitipoca } \\
\hline A & $0-15$ & $3 / 12.5 \mathrm{Y}$ & 23 & 50 & 16 & 11 & 0.5 & 4.8 & 0.2 & 1.9 & 12 & 19 & 32 & 1.0 \\
\hline $\mathrm{C}$ & $15-45$ & $5 / 32.5 \mathrm{Y}$ & 58 & 27 & 10 & 5 & 1.2 & 5.0 & 0.0 & 0.6 & 3 & - & - & - \\
\hline \multicolumn{15}{|c|}{ "Neossolo litólico hístico"1 (quartzite) - Itacolomi } \\
\hline $\mathrm{O}$ & $0-25$ & $1 / 0$ & - & - & - & - & 0.9 & 3.9 & 1.0 & 14.3 & 178 & 4 & 71 & 3.1 \\
\hline \multicolumn{15}{|c|}{ "Neossolo litólico hístico"1 (granite) - Caparaó } \\
\hline $\mathrm{O}$ & $0-15$ & $1.5 / 110 \mathrm{YR}$ & - & - & - & - & 14.1 & 5.3 & 0.3 & 3.0 & 164 & 18 & 51 & 2.2 \\
\hline \multicolumn{15}{|c|}{ "Neossolo litólico hístico"1 (sienite) - Itatiaia } \\
\hline $\mathrm{O}$ & $0-12$ & 1.5/1 10YR & - & - & - & - & 11.5 & 5.1 & 0.4 & 6.7 & 123 & 24 & 35 & 1.4 \\
\hline \multicolumn{15}{|c|}{ "Neossolo litólico hístico"1 (quartzite) - Diamantina } \\
\hline $\mathrm{H}$ & $0-15$ & $2 / 0$ & - & - & - & - & 1.3 & 3.7 & 1.7 & 6.0 & 274 & 10 & 25 & 0.5 \\
\hline
\end{tabular}

1 Brazilian Soil Classification System (Embrapa 1999). 
present. These soils that consist of an organic layer thicker than $40 \mathrm{~cm}$, resting directly on the rock or saprolite are classified as "Organossolos" (Embrapa 1999) and correspond to Histosols (USDA 1998, FAO 1998). The peatlands have an important environmental role regarding water resources and $\mathrm{C}$ sequestration. During the rainy season they are waterlogged, being gradually drained throughout the dry season, regulating water flow of streams and high watersheds. These geoenvironments with deep organic accumulations also present extremely high C stocks (Simas et al. 2005).

The Histosols are associated to the rock outcrops and grassy fields normally cover them. However, they have also been described in the Mantiqueira, under dense Atlantic forest, suggesting a broader presence of this soil class in altitudes $>1,600 \mathrm{~m}$ on igneous and metamorphic lithologies (Benites et al. 2001, Simas et al. 2005). As landscape develops, parts of former marshy peats become sufficiently dry due to the establishment of the drainage system, enabling the growth of forest vegetation, but keeping its high $\mathrm{C}$ content. Due to the strongly humified nature of the organic material, the Histosols associated to the outcrops in the Mantiqueira mountain range are classified as sapric (table 4).

Another important pedogenetic process that could normally be observed on the high altitude rocky complexes is the podzolization. Podzolization is a well-known soil forming process, especially in temperate climates. This process consists on the eluviation of soluble organic compounds associated with $\mathrm{Fe}$ and $\mathrm{Al}$, leaching throughout the profile (De Coninck 1980). Consequently, this process leads to residual quartz concentration as sand particles in the upper horizons and a formation of a Spodic B horizon, which shows illuvial subsurface accumulation of organic substances and $\mathrm{Al}$ and $\mathrm{Fe}$ compounds. These soils are classified as "Espodossolos" (Embrapa 1999) and correspond to Spodosols (USDA 1998) and Podzols (FAO 1998). In Brazil, there are few studies on Spodosols especially in mountainous environments (Benites et al. 2001, Dias et al. 2002, Simas et al. 2005). Due to the little thickness and low nutrient retention capacity of soils from high altitude rocky complexes, part of the organo-metalic compounds can reach down the profile forming thin deposits in the contact between the rock and the solum, or reach the groundwater.

In quartzite areas, where coarse textured soils are predominant, it is possible to observe the dark color of waters caused by the illuviation of organo-metalic compounds. Losses of organic substances in the rivers represent an important component of the carbon cycle in the ecosystem. Large amounts of carbon leave the soil

Table 4. Characteristics of Histosols (Lithic Haplosaprists) associated with different rock outcrops in Mantiqueira and Espinhaço. ( $\mathrm{cs}=$ coarse sand, $\mathrm{fs}=$ fine sand, $\mathrm{Fe}_{\mathrm{DCB}}=$ Free $\mathrm{Fe}$ extracted with dithionite-citrate-bicarbonate, $\mathrm{TOC}=$ total organic carbon, $\mathrm{FA}=$ fulvic acid fraction, $\mathrm{HA}=$ humic acid fraction, $\mathrm{AE} / \mathrm{H}=$ alcaline exctract/humin ratio).

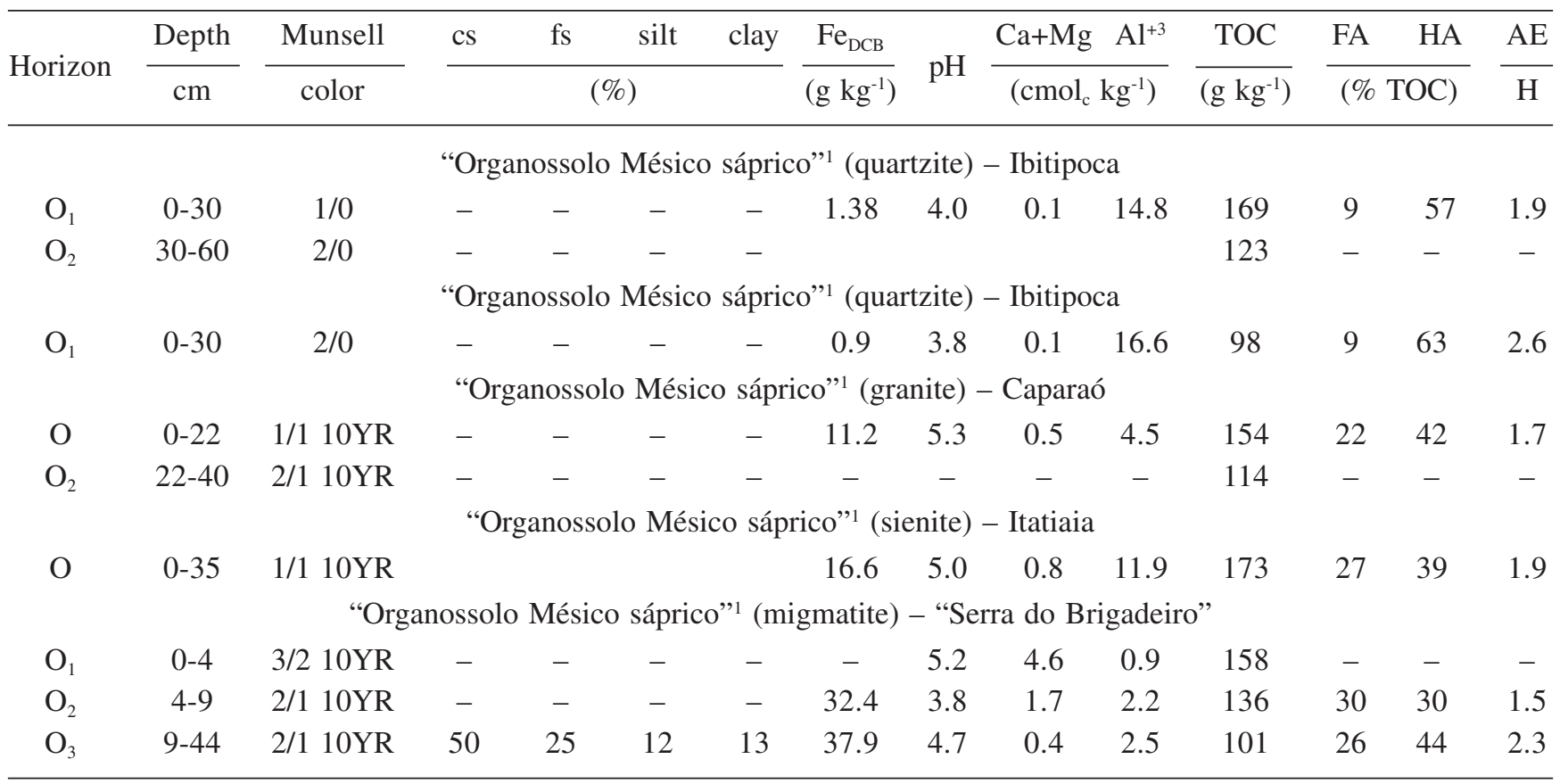

1 Brazilian Soil Classification System (Embrapa 1999). 
system in the areas associated with the quartzite outcrops. On the other hand, the primary biomass production is low due the limitations induced by the nutrient deficient soils, suggesting a negative carbon balance in the soil. This is an evidence that the mountainous soils associated with quartzite in Brazil are facing a natural degradation process under the current warmer climatic conditions. Anthropic activities such as deforestation, induced fires, and uncontrolled tourism in some areas strongly contribute to the degradation process.

In the Mantiqueira Range, although the soils are also well drained, the presence of small amounts of clay in the profiles promotes the filtration of the soil solution, holding back soluble organic compounds (Benites et al. 2001). In these soils there are high concentrations of soluble organic substances in the form of fulvic acids, associated with poorly crystalline $\mathrm{Fe}$ and $\mathrm{Al}$ minerals. Soil mapping in soils associated with rock outcrops - In soil surveys, the different pedoenvironments are represented by mapping units. Each unit is formed by a soil association represented by the predominant soil class and inclusions. Considering the high heterogeneity of soil classes associated with rock outcrops, it is practically impossible to identify mapping units represented by a single soil class. More detailed surveys would be necessary (scale greater than 1:1,000) to allow the individualization of these unique pedoenvironments. However, this type of information can be very useful for botanical studies regarding edaphic control on vegetation distribution.

Few soil surveys in detailed scale have been carried out in soils associated with rock outcrops of Mantiqueira and Espinhaço. Geoenvironmental studies have been developed in the "Parque Estadual de Ibitipoca" (scale 1: 5,000) (Dias et al. 2002) and in the Papagaio and Serra Verde mountain ranges (1:10,000 scale) (Simas et al. 2005). In the soil map of Brazil, scale 1:5,000,000 (Embrapa 2001), soils associated with rock outcrops are represented by mapping units in which the Entisols constitute the predominant soil class in quartzite areas and Inceptisol or Red Yellow Oxisol in granitic areas.

Due to the little detailed information on the distribution of highland soils in Brazil, the importance of these environments has not yet been fully addressed. Actions looking for the conservation of these ecosystems are limited due to the lack of maps in small scales. For example, the mapping units that represent these areas lead to an underestimation of the soil total C stocks because inclusions of carbon rich soils are not considered. Simas et al. (2005) have shown that altitude rocky complexes may contain much higher total $\mathrm{C}$ stocks than secondary forest areas.
The extremely low nutrient status of all mineral soil horizons studied reveals the important role of nutrient cycling mechanisms in the sustainability of these natural environments. Despite the general landscape renewal promoted by current morphogenesis, the low nutrient reserve of pre-weathered saprolites favor the formation of extremely poor soils. Soil depth is strongly influenced by parent material and topography.

Although the rock outcrops are extremely important areas for environmental conservation, many scientific questions remain open. More detailed studies are needed for a better understanding of the potentials and limitations of these environments, with emphasis on more detailed soil surveys. These studies are essential for the development of management/conservation strategies and a better understanding of soil endemism and associated factors controlling vegetation distribution in soil associated with rock outcrops.

Acknowledgements - The authors are grateful to IBAMA and to IEF for the soil sampling permit. We also thank Dr. Pedro Machado for his valuable suggestions.

\section{References}

BENITES, V.M., KER, J.C. \& MEDONÇA, E.S. 2000. Fracionamento quantitativo de substâncias húmicas como auxiliar na identificação de diferentes solos da região sul do Brasil - VI RCC. In Guia de excursão de estudos de solos nos estados do Rio Grande do Sul, Santa Catarina e Paraná (G.R. Curcio et al., eds.). Embrapa Florestas, Colombo, p.87-99.

BENITES, V.M., SCHAEFER, C.E.G.R., MENDONÇA, E.S. \& MARTIN NETO, L. 2001. Caracterização da matéria orgânica e micromorfologia de solos sob Campos de Altitude no Parque Estadual da Serra do Brigadeiro. Revista Brasileira de Ciências de Solo 25:661-674.

BENITES, V.M., CAIAFA, A.N., MENDONÇA, E.S., SCHAEFFER, C.E.G.R. \& KER, J.C. 2003a. Solos e vegetação nos Complexos Rupestres de Altitude da Mantiqueira e do Espinhaço. Revista Floresta e Ambiente 10:76-85.

BENITES, V.M., CUNHA, T.J.F., FERRAZ, R.P.D., CAIAFA, A.N., SIMAS, F.N.B. \& MENDONÇA, E.S. 2003b. Caracterização de solos em duas topossequências em diferentes litologias em áreas altimontanas na Serra da Mantiqueira. Boletim de Pesquisa 57, Embrapa Solos, Rio de Janeiro.

BENITES, V.M., MADARI, B. \& MACHADO, P.L.O.A. 2003c. Fracionamento quantitativo de substâncias húmicas: um procedimento simplificado e de baixo custo. Comunicado Técnico 8, Embrapa Solos, Rio de Janeiro. 
BENITES, V.M., MENDONÇA, E.S., SCHAEFER, C.E.G.R, NOVOTNY, E.H., REIS, E.L. \& KER, J.C. 2005. Properties of black soil humic acids from high altitude rocky complexes in Brazil. Geoderma 127:104113.

BIODIVERSITAS. 1999. Atlas das prioridades para conservação da biodiversidade do Estado de Minas Gerais. Fundação Biodiversitas, Belo Horizonte.

DE CONINCK, F. 1980. Major mechanisms in formation of spodic horizons. Geoderma 24:101-128.

DIAS, H.C.T., FERNANDES, E.I.F, SCHAEFER, C.E.G.R., FONTES, L.E.F. \& VENTORIM, L.B. 2002. Geoambientes do Parque Estadual do Ibitipoca, Município de Lima Duarte-MG. Revista Árvore 26:777-786.

EMBRAPA. 1997. Manual de métodos e análises de solo. Embrapa Solos, Rio de Janeiro.

EMBRAPA. 1999. Sistema brasileiro de classificação de solos. Embrapa Solos, Rio de Janeiro.

EMBRAPA. 2001. Mapa de Solos do Brasil em escala 1:5.000.000. Embrapa Solos, Rio de Janeiro.

FAO. 1998. World reference base for soil resources. World Soil Resources Report 84, FAO/ISRIC/ISSS, Rome.

JOLY, A.B. 1970. Conheça a vegetação brasileira. EDUSP, São Paulo.

MYERS, N., MITTERMEIER, R.A., MITTERMEIER, C. G., FONSECA, G.A.B. \& KENT, J. 2000. Biodiversity hotspots for conservation priorities. Nature 403:853858 .
SCHAEFER, C.E.G.R., KER, J.C., GILKES, R.J., CAMPOS, J.C., DA COSTA, L.M. \& SAADI, A. 2002. Pedogenesis on the uplands of the Diamantina Plateau, Minas Gerais, Brazil: A chemical and micropedological study. Geoderma 107:243-269.

SEMIR, J. 1991. Revisão taxonômica de Lychnophora Mart. (Vernoniaceae: Compositae). Tese de doutorado, Universidade Estadual de Campinas, Campinas.

SIMAS, F.N.B., SCHAEFER, C.E.G.R., FERNANDES FILHO, E.I., CHAGAS, A.C. \& BRANDÃO, P.C. 2005. Chemistry, mineralogy and micropedology of highland soils on crystalline rocks of the Serra da Mantiqueira, southeastern Brazil. Geoderma 125:187201.

USDA. 1998. Keys to soil taxonomy. United States Department of Agriculture, New York.

VAN BREEMAN, N., FINLAY, R., LUNSTROM, U., JONGMANS, A., GIESLER, R. \& OLSSON, M. 2000. Mycorrhizal weathering: A true case of mineral plant nutrition? Biogeochemistry 49:53-67.

VOLKOFF, B., CERRI, C.C. \& MELFI, A.J. 1984. Húmus e a mineralogia dos horizontes superficiais de três solos de campos de altitude dos estados de Minas Gerais, Paraná e Santa Catarina. Revista Brasileira de Ciências de Solo 8:277-283.

YEOMANS, J.C. \& BREMNER, J.M. 1988. A rapid and precise method for routine determination of organic carbon in soil. Communications in Soil Science and Plant Analysis 19:1467-1476. 